doi:10.32620/oikit.2018.81.09

УДК 519.92:007:621.438(076.5):629.735.33.016 В. П. Герасименко

\title{
Деякі відмінності ГТД різного призначення
}

\author{
Національний аерокосмічний університет ім. М.Є. Жуковського \\ "Харківський авіаційний інститут»
}

\begin{abstract}
Розглянуто різне застосування газотурбінних двигунів (ГТД) і визначено основні ознаки, що їх поєднують. Виділено найбільш поширені авіаційні ГТД (АГТД). Уведено поняття «вільна робота» і показано її зв'язок з основними термогазодинамічними параметрами АГТД. Деталізовано класифікацію АГТД і здійснено кластерний аналіз. Як кластери - таксони виділено газогенератори. Як ознаки кластерізації використано рівні термодинамічних параметрів, а також конструктивні схеми. Обґрунтовано подальший розвиток АГТД.

Ключові слова: літак, газотурбінний двигун, газогенератор, компресор.
\end{abstract}

Газотурбінні двигуни (ГТД) широко застосовують в авіації, морському транспорті, наземних транспортних засобах, енергетиці, у нафтогазовій галузі, для чого необхідно використовувати різноманітні достатньо складні та досконалі схеми реалізації з високим рівнем ефективних показників і параметрів робочого процесу. Лише авіаційні ГТД нараховують близько двох десятків типів згідно з існуючою класифрікацією [1-4] - від ГТД безпілотних літальних апаратів одноразового використання до турбореактивних двигунів змінного робочого процесу (ТРДЗ) і турбогвинтовентиляторних (ТГВД).

Метою даної роботи є з'ясування особливостей у формуванні обрису і параметричних відмінностей ГТД різного призначення шляхом термогазодинамічного аналізу для визначення перспектив подальшого їх розвитку. До основних ознак, що поєднують ГТД, можна віднести:

- існує газогенератор, в якому генерується газ із «вільною енергією» шляхом згоряння палива в умовах з підвищеним тиском повітря і за яким частина цієї енергії у кількості вільної роботи $\mathrm{L}_{\text {віл }}$ витрачається для виконання основної фрункції двигуна - створення реактивної тяги чи потужності на валу $[4,5]$;

- ГТД є складною технічною системою, де відбуваються не менш складні різні за природою термогазодинамічні робочі процеси зі згорянням палива;

- ГТД призначені для більш складних систем, що дозволяє розглядати їх проектування з позицій системного підходу як багаторівневий процес [3, 5].

Незважаючи на перераховані схожі ознаки ГТД, існують також суттєві відмінності, що визначаються їх призначенням та умовами експлуатації [5], для обгрунтування яких розробляють математичні методи розпізнавання образів [6, 7].

\section{1. Термогазодинамічний аналіз авіаційних ГТД}

\section{1. Аналіз ГТД дозвукових літаків}

Сучасний стан розвитку авіаційних газотурбінних двигунів (ГТД) характеризується високим рівнем термогазодинамічної досконалості і відповідає VI поколінню (рисунок) [1, 2], для якого помітно знизився темп поліпшення їх основних питомих параметрів і особливо питомої витрати палива $\mathrm{C}_{\text {п }}$ і питомої маси $\gamma_{\text {дв }}$, що свідчить про досягнення за цими показниками граничних можливостей, які отримали назву «термодинамічне насичення» [3]. Отже, згідно зі статистичними даними (ри- 
сунок), наведеними в основному для турбореактивних двоконтурних двигунів (ТРДД), досягнуто порівняно високі основні параметри робочого процесу $\pi_{\kappa_{\Sigma}}^{*} \mathrm{i} \mathrm{T}_{\Gamma}^{*}$ $\left(\pi_{\mathrm{K}_{\Sigma}}^{*} \approx 50 \mathrm{i} \mathrm{T}_{\Gamma}^{*} \approx 1800 \mathrm{~K}\right)$, що визначають власне рівень термодинамічної досконалості газогенераторної частини двигуна $[4,5]$, вихідною характеристикою якої $є$ вільна робота $\mathrm{L}_{\text {віл }}=\mathrm{f}\left(\pi_{\mathrm{K}_{\Sigma}}^{*}, \mathrm{~T}_{\Gamma}^{*}\right)(1)$.

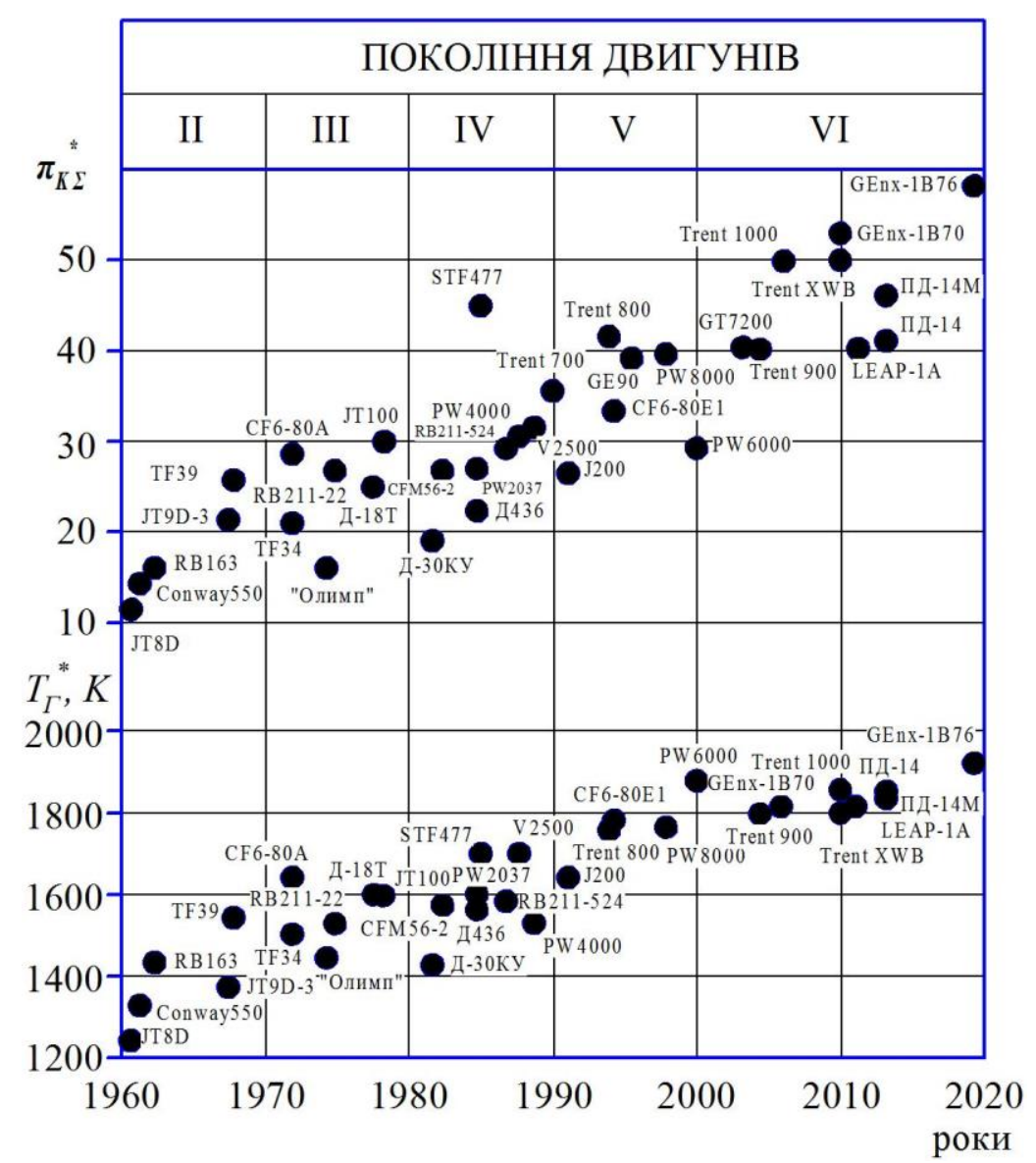

Тенденція зміни параметрів робочого процесу авіаційних

ГТД за поколіннями

$$
\mathrm{L}_{\text {віл }}=\mathrm{c}_{\mathrm{p} \Gamma} \mathrm{T}_{\Gamma}^{*}\left(1-\mathrm{l}_{\mathrm{TK}}^{*}\right)\left\{1-1 /\left[\sigma_{\mathrm{Bx}}\left(1+\frac{\mathrm{k}-1}{2} \mathrm{M}_{\Pi}^{2}\right)^{\frac{\mathrm{\kappa}}{\mathrm{\kappa}-1}} \pi_{\mathrm{\kappa} \Sigma \mathrm{I}}^{*} \sigma_{\mathrm{KC}}\right]^{\frac{\mathrm{k}_{\Gamma}-1}{\mathrm{~K}_{\mathrm{\Gamma}}}}\left(1-\frac{\mathrm{l}_{\mathrm{TK}}^{*}}{\eta_{\text {TК }}^{*}}\right)\right\},
$$

де $1_{\mathrm{TK}}^{*}=\mathrm{c}_{\mathrm{p}} \mathrm{T}_{\mathrm{H}}^{*}\left(\pi_{\kappa \Sigma \mathrm{I}}^{*}{ }^{\frac{\kappa-1}{\kappa}}-1\right) / \mathrm{c}_{\mathrm{p} \Gamma} \mathrm{T}_{\Gamma}^{*} \eta_{\kappa \Sigma \mathrm{I}}^{*} \eta_{\mathrm{m}}-$ питома робота турбіни компресора; $\mathrm{c}_{\mathrm{p}}, \mathrm{c}_{\mathrm{p}_{\Gamma}}$, к, $\kappa_{\Gamma}$ - теплоємності і показники ізоентропи повітря і газу відповідно; $\eta_{\kappa \Sigma I}^{*}, \eta_{\text {тк }}^{*}, \eta_{\mathrm{m}}-$ ККД компресора внутрішнього контуру, турбіни компресора і механічний; $\sigma_{\text {вх }}, \sigma_{\text {Кз }}$ коефіцієнти відновлення повного тиску у вхідному пристрої і камері згоряння.

$\mathrm{L}_{\text {віл }}$ однозначно пов'язана з питомою тягою $\mathrm{P}_{\text {п }}$ [4]. Проте $\mathrm{P}_{\text {п }}$ на відміну від $\mathrm{L}_{\text {віл }}$ залежить також від степеня двоконтурності m ТРДД, що в основному використовують у сучасній дозвуковій пасажирській і транспортній авіації. Підвищення паливної економічності двигунів VI покоління відбулося головним чином шляхом 
значного збільшення $\mathrm{m}$ ТРДД до $\mathrm{m}=15 \ldots 25$ та $\mathrm{m}=30 \ldots 60$ турбогвинтовентиляторних двигунів (ТГВД) [3]. Звичайно m визначають на стадії фрормування обрису двигуна як силової установки літака з узгодженням їх характеристик за критеріями ефективності літаків [3, 4]. Наявність вибраного m дозволяє здійснювати оптимізацію розподілу $\mathrm{L}_{\text {віл }}$ між контурами ТРДД для забезпечення максимальної питомої тяги $\mathrm{P}_{\text {пmax }}$. За результатами оптимізації визначають степінь підвищення тиску вен-

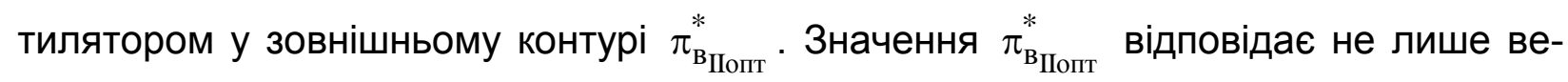

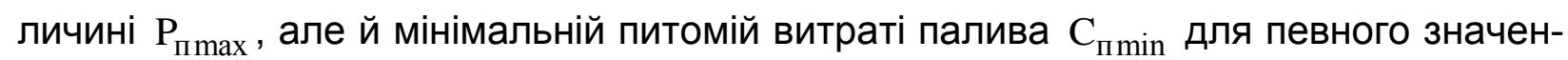
ня $\mathrm{m}$ ТРДД чи ТГВД. Враховуючи пологість залежностей $\mathrm{P}_{\Pi}=\mathrm{f}\left(\mathrm{m}, \pi_{\mathrm{B}_{\mathrm{II}}}^{*}\right)$ i $\mathrm{C}_{\Pi}=\mathrm{f}\left(\mathrm{m}, \pi_{\mathrm{B}_{\text {II }}}^{*}\right)$, у практиці проектування двигунів допускають відхилення від оптимальних значень $\pi_{\mathrm{B}_{\text {IIопт }}^{*}}^{*}$ з метою зменшення кількості ступенів турбіни вентилятора.

Необхідно мати на увазі, що критерії ефективності (оптимізації) дозвукових пасажирських і транспортних літаків, за якими погоджують їх характеристики з характеристиками двигунів, розподіляють на економічні, льотно-технічні, енергетичні та масові [3], між якими існують певні однозначні зв'язки [4]. Серед них сумарна питома маса палива і двигуна $\gamma_{\Sigma}$, з одного боку, являє собою основу більшості критеріїв, а з іншого - поєднує питому витрату палива $\mathrm{C}_{\Pi_{\text {кр }}}$ з питомою масою двигуна $\gamma_{\text {дв }}$.

$$
\gamma_{\Sigma}=\mathrm{C}_{\text {Пкр еф }} \cdot \mathrm{t}_{\Pi}+\gamma_{\text {дв кр еф }} \cdot \mathrm{k}_{\text {су }},
$$

де $\mathrm{C}_{\Pi \text { еф }}=\mathrm{G}_{\Pi} / \mathrm{P}_{\text {еф }} ; \mathrm{k}_{\text {су }}=\mathrm{M}_{\text {су }} / \mathrm{M}_{\text {дв }}=1,4 \ldots 1,6 ; \mathrm{G}_{\Pi}$ - витрата палива; $\mathrm{P}_{\mathrm{e \phi}}$ - ефективна тяга двигуна; $\mathrm{M}_{\text {су }}$ - маса силової установки; $\mathrm{M}_{\text {дв }}$ - маса двигуна.

3 позиції системного підходу [3] за багаторівневим ієрархічним процесом оптимізації $\gamma_{\Sigma}=\mathrm{f}\left(\pi_{\kappa_{\Sigma}}^{*}, \mathrm{~T}_{\Gamma}^{*}, \mathrm{~m}, \pi_{\mathrm{B}_{\mathrm{II}}}^{*}\right)$ як критерій оцінювання ефективності літака може бути використаний в оптимізації параметрів двигуна як підсистеми літака. Отже за цим критерієм $\gamma_{\Sigma}=\mathrm{f}\left(\pi_{\mathrm{K}_{\Sigma}}^{*}, \mathrm{~T}_{\Gamma}^{*}, \mathrm{~m}, \pi_{\mathrm{B}_{\text {II }}}^{*}\right)$ визначають $\mathrm{m}_{\text {опт } \gamma} \mathrm{i} \pi_{\mathrm{\kappa} \Sigma \text { опт } \gamma}^{*}[3,4]$. І оскільки $\mathrm{T}_{\Gamma}^{*}$ часто задають на рівні технічної досконалості за можливості, близької до $\mathrm{T}_{\Gamma \text { ек }}^{*}$ [4], то $\pi_{\kappa \Sigma \text { оп }}^{*}$ і $\mathrm{T}_{\Gamma \text { ек }}^{*} €$ визначальними у «термодинамічному насиченні», за якого підвищення ККД вузлів ГТД шляхом просторового проектування розглядають, як суттєвий резерв підвищення економічності авіаційних ГТД [3].

Слід також зазначити, що вільна робота відповідно до формули (1) як вихідна характеристика газогенераторної частини - кластера-таксона [7] двигуна більш високого ієрархічного рівня залежить не лише від параметрів циклу $\pi_{\kappa_{\Sigma}}^{*} \mathrm{i} \mathrm{T}_{\Gamma}^{*}$, як окремих ознак розпізнавання «термодинамічного насичення» в ознаковому просторі образів [6, 7], але і від газодинамічної досконалості проточної частини газогенератора, що визначається рівнем економічних показників вузлів, зокрема $\eta_{\kappa_{\Sigma I}}^{*}$ сумарного ККД компресора внутрішнього контуру і $\eta_{\text {тк }}^{*}$ ККД турбіни компресора, $\sigma_{\text {вх }}$ i $\sigma_{\text {кс }}-$ коефріцієнтів відновлення повного тиску у вхідному пристрої і основній 
камері згоряння. Серед названих показників $\eta_{\kappa_{\Sigma I}}^{*} \epsilon$ найбільш визначальним щодо можливостей подальшого прогресу у розвитку авіаційних двигунів. Таким чином, як системний ієрархічний підхід, запропонований І.Ф. Флоровим [3], з рівнями літак ГТД, так і аналіз фрормули (1), що доповнює систему газогенератором за критеріями $\gamma_{\Sigma}-\mathrm{P}_{\Pi}-\mathrm{L}_{\text {віл }}$ як сукупності ознак розпізнавання [6] газогенератора як кластератаксона [7], дозволяють виділити термодинамічні параметри насичення $\pi_{\kappa_{\Sigma I}}^{*} \mathrm{i} \mathrm{T}_{\Gamma}^{*} \mathrm{i}$ газодинамічні параметри газогенератора $\eta_{\kappa_{\Sigma I}}^{*}, \eta_{\text {тк }_{\mathrm{I}}}^{*} \sigma_{\text {кс }}$, шляхом підвищення яких, окрім m, можливе подальше удосконалення ГТД у системі літак.

На загальний ККД ТРДД із великим m, а також ТГВД суттєво впливає аеродинамічна досконалість вентилятора і гвинтовентилятора з шаблеподібними лопатями або обандаженим робочим колесом вентилятора, як у ТРДД CFM.56, SaM146, Д-30КП «Бурлак» [3]. Удосконалення гвинтовентилятора чи вентилятора підвищує тяговий ККД двигуна у бік збільшення крейсерської швидкості польоту літака, що, незважаючи на можливе при цьому зменшення ефективного ККД, сприяє поліпшенню паливної економічності $[1,3,4]$. Доречно зазначити, що SaM-146 i Д-30КП «Бурлак», як і CFM.56 з m=6, $\pi_{\kappa}^{*}=29, \mathrm{~T}_{\Gamma}^{*}=1560$ К, який створений у IV поколінні на основі газогенератора ТРДДФ F101 - як перспективного фрірми Джене-

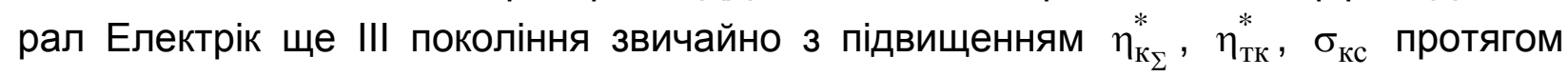
останніх років, також розроблялися за методологією застосування перспективного газогенератора, але пізніше. CFM.56 різних модифікацій використовували на декількох типах дозвукових транспортних літаків спеціального призначення. Величина $\mathrm{m} \in$ визначальною ознакою типу ГТД за належністю призначення.

Зазначимо, що газогенератори авіаційних ГТД попередніх поколінь часів 1965-85 років з рівнями $\pi_{\kappa_{\Sigma}}^{*}=20 \ldots 30$ і $\mathrm{T}_{\Gamma}^{*}=1450 \ldots 1650$ К були значно віддалені від «термодинамічного насичення», яке досягнене у теперішній час. Отже, виникла нагальна потреба суттєвого поліпшення ефективності газогенераторів використанням якісно нових заходів, зокрема підвищення ККД вузлів газогенератора. Очевидно, зазначені рівні параметрів можуть бути визначальними ознаками не лише ГТД як класів, але і газогенераторів за використанням «найближчого сусіда» [6, 7] у визначенні рівнів досконалості.

\section{2. Аналіз ГТД багаторежимних літаків}

Під багаторежимними літаками звичайно розуміють літаки, польотний цикл яких містить як дозвукові, так і надзвукові швидкості польоту. Для забезпечення надзвукових швидкостей польоту, як правило, використовують форсування двигуна згорянням палива у форсажній камері. Частіше за все до таких двигунів відносять ТРДДФ - турбореактивні двоконтурні двигуни з форсажною камерою. Однією з особливостей ТРДДФ є застосування порівняно малих степенів двоконтурності $\mathrm{m}=0,15 \ldots 0,65$ у надзвуковому польоті, тоді як газогенераторні частини, що характеризуються робочими параметрами $\pi_{\kappa_{\Sigma}}^{*} \mathrm{i} \mathrm{T}_{\Gamma}^{*}$, можуть бути використані практично такими ж, як у ТРДД з дозвуковими швидкостями польоту літака. Прикладом є зазначені вище ТРДД CFM.56, SaM-146, що створені за участі фірми Snecma. 3 іншого ж боку, привертає до себе виняткову увагу простий за конструкцією однова- 
льний ТРДДФ М.53 цієї ж фрірми з малим степенем підвищення тиску $\pi_{\mathrm{K}_{\Sigma}}^{*}=8,5$ i $\mathrm{T}_{\Gamma}^{*}=1473$ К, що значно нижче, ніж параметри «термодинамічного насичення». Звичайно у випадку надзвукових швидкостей польоту $\mathrm{M}_{п} \geq 2,3 \ldots 2,5$ літаків «Міраж» із двигунами М.53 параметри циклу суттєво зростають за рахунок швидкісного стиснення. Мале значення $\pi_{\mathrm{K}}^{*}$, з одного боку, сприяє зменшенню $\gamma_{\text {дв }}$, а з іншого - збільшенню $\eta_{\kappa}^{*}$ компресора з удосконаленими ступенями і значно поліпшеними їх ККД $\eta_{\mathrm{cт}}^{*} \approx 0,93 \ldots 0,95[2,6]$. ТРДДФ більшості ж фірм F100, F101, F404, TF30, РД-33, Д-30Ф6, АЛ-31Ф того ж покоління були виконані за двовальною схемою 3 $\pi_{\mathrm{K}}^{*}=21 \ldots 27$, хоча і меншими, ніж за «термодинамічного насичення», але значно більшими $\pi_{\kappa}^{*}$, ніж 8,5 ТРДДФ М.53 [3, 6]. Винятком є ТРДДФ RB.199, що виконаний за тривальною схемою, але $3 \pi_{\mathrm{K}}^{*}=23,4$. Проте, незважаючи на наведені відмінності ТРДДФ різних фрірм, удосконалення газогенераторів шляхом просторових методів розрахунку залишається актуальним [3].

\section{2. Відмінності неавіаційних ГТД}

Фахівцям цілком зрозуміло, що на відміну від авіаційних ГТД ГТД сучасних наземних транспортних засобів, газоперекачувальних агрегатів, енергетичних установок і морського транспорту знаходяться на рівні III авіаційного покоління, тобто у розвитку запізнюються на 40-50 років, а отже, «термодинамічне насичення» не є перепоною традиційного поліпшення ефективності їх газогенераторів. 3 іншого боку, існують можливості для підвищення паливної економічності шляхом застосування регенерації теплоти та системи STIG, охолодження циклового повітря у компресорі, використання парогазових установок або оптимального регулювання для поліпшення експлуатаційних характеристик, наприклад, поворотом соплових лопаток силової турбіни. Багатофункціональні суднові комбіновані силові установки призначені для приводу суднових гвинтів, вироблення теплової і електричної енергії, кондиціювання повітря у приміщеннях, охолодження холодильних камер і обладнання. Отже, зазначені відмінності є достатньо принциповими особливостями - ознаками застосування ГТД за різним призначенням, тобто розподілу класу ГТД на підкласи $[6,7]$.

\section{Висновки}

Таким чином, підвищення КПД компресорних ступенів є визначальним заходом поліпшення ефективності двигунів як в умовах «термодинамічного насичення», так і за помірних значень параметрів робочого процесу $\pi_{\kappa_{\Sigma}}^{*}$ i $\mathrm{T}_{\Gamma}^{*}$, зокрема ГТД авіаційного призначення. Згідно з [3-5, 6,7] визначальною ознакою належності ГТД до класу авіаційних двигунів $є$ використання параметра $\mathrm{m}$. Причому у випадку $0 \leq \mathrm{m} \leq 1,0$ розглянуті двигуни, як правило, відносяться до підкласу ТРДДФ, в якому наявність форсажної камери згоряння $є$ додатковою ознакою авіаційного ГТД (винятком був двигун F101 з m=2,0). У цих випадках удосконалення двигунів здійснюють шляхом підвищення ККД $\eta_{\kappa}^{*}$ з урахуванням «термодинамічного насичення».

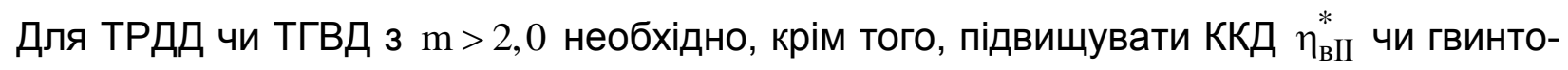
вентилятора (як це у Д-ЗОКП «Бурлак» з шаблеподібними лопастями). 
У наземному випадку ГТД класу ТРДД не використовують. Щодо більш глибокого математичного обґрунтування відмінностей і схожих ознак розглянутих ГТД методами розпізнавання образів [6, 7] в оговорених винятках необхідно зазначити обмеженість статистичних виборок для кластеризації газогенераторів ГТД.

\section{Список літератури}

1. Теория авиационных газотурбинных двигателей : учебник / под общ. ред. Ю. М. Терещенко. - Киев : НАУ, 2005. - 500 с.

2. The GEnx engine [Электронный ресурc]. URL: http://www.geaviation.com/commercial/engines/genx-engine (дата обращения 11.07.2018).

3. Теория, расчет и проектирование авиационных двигателей и энергетических установок : учебник. Кн. 3. / под общ. ред. В. В. Кулагина. - М.: Машиностроение, 2005. - 464 с.

4. Герасименко, В.П.Теорія авіаційних двигунів : підручник / В. П. Герасименко. - Харків : XAI,- 2003. - 199 с.

5. Cohen, H., Saravanamuttoo H. Gas Turbine Theory. / H. Cohen, G. Rogers. 4-th edition. Harlow : Longman Group Limited, 1996. - 455 p.

6. Классификация и кластер / ред. Дж. В. Райзин; пер. с англ. Под ред. Ю.И. Журавлева. - М.: Мир, 1980. - 390 с.

7. Загоруйко, Н.Г. Методы распознавания и их применение. - М.: Сов. радио, 1972. -212 с.

Надійшла до редакції 25.09.2018

\section{Некоторые отличия ГТД разного назначения}

Рассмотрено различное использование газотурбинных двигателей (ГТД) и определены основные признаки, их объединяющие. Выделены наиболее распространенные авиационные ГТД (АГТД). Введено понятие «свободная работа» и показана ее связь с основными термогазодинамическими параметрами АГТД. Детализирована классификация АГТД и проведен кластерный анализ. В качестве кластеров-таксонов приняты газогенераторы. В качестве признаков кластеризации использованы уровни термодинамических параметров и конструкционные схемы.

Ключевые слова: самолет, газотурбинный двигатель, газогенератор, компрессор.

\section{Some differences of various usage GTE}

It has been investigated the use of gas-turbin engine and the main signs of GTE have been determed. The most spread aviation engine have been determed. The new definition "free work" has been created and basic parameter AGTE. The classification of AGTE has been detalized and klaster analysis with the determination of the egnal. As klasters - taxons the gasgenerators groups of engines has been used.

Keywords: aircraft, gasturbineengine, gasgenerator, compressor.

\section{Відомості про автора:}

Герасименко Володимир Петрович - д-р техн. наук, проф., профр. кафедри Теорії авіаційних двигунів, Національний аерокосмічний університет ім. М.Є. Жуковського «XAl». 